\title{
Promoting spiritual paths in graduate nursing students in time of COVID-19
}

\author{
Promovendo caminhos espirituais em estudantes de graduação em enfermagem em tempo de
}

COVID-19

Promoviendo caminos espirituales en estudiantes graduados de enfermería en tiempos de

COVID-19

Paula Encarnação

ORCID: https://orcid.org/0000-0002-7458-8105 University of Minho, School of Nursing, Portugal UICISA-E, School of Nursing, Coimbra, Portugal E-mail: pse@ese.uminho.pt

Benedita Leite

ORCID: https://orcid.org/0000-0001-5757-7650 University of Minho, School of Nursing, Portugal E-mail: benicleite@hotmail.com

Joana Magalhães

ORCID: https://orcid.org/0000-0002-1872-5873 University of Minho, School of Nursing, Portugal E-mail: joanamagalhaes04@hotmail.com

Sara Ferreira

ORCID: https://orcid.org/0000-0002-8245-1336 University of Minho, School of Nursing, Portugal E-mail: sara-isabel-ferreira@hotmail.com

Patrícia Araújo

ORCID: https://orcid.org/0000-0003-4364-567X University of Minho, School of Nursing, Portugal E-mail: patriciaisaraujo24@gmail.com

\begin{abstract}
The COVID-19 pandemic caused alterations within all aspects of human life, which enabled students to uncover fears. These negative emotions, even for training nursing students, can become contagious within and between families, family members and friends, dominating and clouding their judgment. So, how do you manage fear? This study aims to describe the experience of five graduating nursing students and their respective teacher in rebuilding and promoting positive emotions (e.g. optimism, hope, courage) through a digital tool (a Blog) throughout the imposed quarantine time. A descriptive study, experience report type, analyse the authors lived experiences during the mandatory quarantine period that emerged due to COVID-19 virus, between March and May of 2020. Symbolic interactionism is used as a philosophical base that guided data collection and analysis. Through the report of their lived experiences, we encountered that the Blog empowered teacher and students to achieve their goals and find new meanings in their lives through three spiritual paths: compassion and kindness; self-awareness and courage. All participants agreed that this kind of digital tool should be used throughout the bachelor's in nursing, which generates a more humanized way of teaching, allowing students to see beyond University walls.
\end{abstract}

Keywords: Nursing; COVID-19; Spiritual paths.

\section{Resumo}

A pandemia por COVID-19 causou alterações em todos os aspetos da vida humana, o que permitiu aos estudantes revelar medos e receios. Essas emoções negativas, mesmo para o estudantes de enfermagem, treinados, podem se tornar contagiosas dentro e entre famílias, familiares e amigos, dominando e obscurecendo seu julgamento. Então, como gerenciar esse medo? Este estudo tem como objetivo descrever a experiência de cinco graduandos de enfermagem e seu respectivo professor na reconstrução e promoção de emoções positivas (por exemplo, otimismo, esperança, coragem) por meio de uma ferramenta digital (um Blog) ao longo do tempo de quarentena imposto. Estudo descritivo, tipo relato de experiência, analisa as experiências vividas pelos autores durante o período de quarentena obrigatória que surgiu em função do vírus COVID-19, entre março e maio de 2020. O interacionismo simbólico é utilizado como base filosófica que norteou a coleta e análise dos dados. Por meio do relato de suas experiências vividas, constatamos que o Blog capacitou professores e alunos a atingirem seus objetivos e encontrarem novos significados em suas vidas por meio de três caminhos espirituais: compaixão e bondade; autoconsciência e coragem. Todos os participantes concordaram que este tipo de ferramenta digital deve ser utilizado ao longo da graduação em 
enfermagem, o que gera uma forma de ensino mais humanizada, permitindo que os alunos olhem para além dos muros da Universidade.

Palavras-chave: Enfermagem; COVID-19; Caminhos espirituais.

\section{Resumen}

La pandemia de COVID-19 provocó alteraciones en todos los aspectos de la vida humana, lo que permitió a los estudiantes descubrir miedo y temor. Estas emociones negativas, incluso para la formación de estudiantes de enfermería, pueden volverse contagiosas dentro y entre familias, miembros de la familia y amigos, dominando y nublando su juicio. Entonces, ¿cómo manejar el miedo? Este estudio tiene como objetivo describir la experiencia de cinco estudiantes de enfermería graduados y su respectivo profesor en la reconstrucción y promoción de emociones positivas (por ejemplo, optimismo, esperanza, coraje) a través de una herramienta digital (un Blog) durante el tiempo de cuarentena impuesto. Estudio descriptivo, tipo relato de experiencia, analiza las experiencias vividas por los autores durante el período de cuarentena obligatoria que surgió debido al virus COVID-19, entre marzo y mayo de 2020. El interaccionismo simbólico se utiliza como base filosófica guío la recolección y análisis de datos. A través del relato de sus experiencias vividas, encontramos que el Blog empoderó al profesor y estudiantes para lograr sus metas y encontrar nuevos significados en sus vidas a través de tres caminos espirituales: la compasión y la bondad; autoconciencia y coraje. Todos los participantes coincidieron en que este tipo de herramienta digital debe ser utilizada a lo largo de la licenciatura en enfermería, lo que genera una forma de enseñar más humanizada, permitiendo a los estudiantes más allá de los muros de la Universidad.

Palabras clave: Enfermería; COVID-19; Caminos espirituales.

\section{Introduction}

All around the world, the COVID-19 pandemic left the population on red alert. The imminence of infection with an unknown and possible lethal virus, made people feel afraid, insecure and threatened. People questioned the consequences that the virus could bring on their lives. They felt threatened by an invisible and unknown danger. Fear spread at a global scale, on real time through the media, which contributed to an increase in stress levels, which could lead people to despair. "People often become depressed and demoralized by repeatedly hearing that something is wrong, missing, or lacking from their lives or health" (Gottlieb 2013, p. xxviii; Ornell et al. 2020; Puchalski 2001). Memory can affect the observer's emotional state and current state of mind. State of mind refers to the emotions a person is experiencing during important or significant events (Bowen, Kark \& Kensinger 2018; Gottlieb 2013).

The brain has a negativity bias as we have learned from brain science. The amygdala activates both, positive and negative emotional experiences but it registers fearful experiences more than positive ones. During this pandemic, our brains seem like they are working overtime in conjuring up fears. When we believe our fears, we open the door to all its companions like discouragement, anger, frustration, and disappointment (Wright, 2020).

In March, Portugal declared a state of emergency, which imposed a mandatory quarantine to all citizens. Several hospitals discontinued clinical rotations for nursing students due to coronavirus (COVID-19) outbreak. This fact delayed students' graduations, when additional nurses were sorely needed to combat the ongoing pandemic. The five nursing students that were currently in the last year of their bachelor's saw their lives disrupted as their last internship (that trains nurses for the beginning of their professional carriers) were suspended. Due to this fact, it was necessary to switch from the traditional way of teaching to online sessions. In the beginning of each online teaching session, there was a 15 minute period where all students were encouraged, by the teacher, to share their emotions. During these sessions, the students revealed strong negative emotions, such as fear and expressed their resentment and indignation towards the fact of not knowing if they could graduate.

These negative emotions, even for training nursing students, can become contagious between them. They could no longer understand how to deal with the situation and which path they should follow. There were no clear answers. Their work performance worsened and their weekly goals were at stake. The desired effect of sharing emotions, feelings and lived experiences wasn't being fulfilled. Instead it was incrementing feelings of insurgency, frustration and fear. At a global scale, 
this extraordinary situation was first hand experienced by everyone. There were no reports that could be used as a strong resource of support and solidarity to help guide the group. Fear was a daily reality within the group. Thus, how do we manage fear, frustration and anguish? "If these fears remain unchecked, they can lead these students to unnecessary suffering" (Wright 2020, p. 188). When exploring the concept of suffering, literature is consistent in relating sadness, fear, anguish, distress, loss; pain and threat to the individuals' integrity as a manifestation of suffering (Cassell 2004; Delio 2020; Encarnação, Oliveira, \& Martins 2018; Wright 2020). Fear can usually be experienced as an unpleasant emotion triggered by a constraining belief. A belief that something unwelcome is about to happen, that something is dangerous or that someone's safety is threatened (Ornell et al. 2020). "The more we resist, the more fearful we become, and the more we suffer [...]. The key to managing our fears is to calm the amygdala. Optimism, hope, and courage come from a heart and brain not burdened by fears“ (Wright 2020, p.188).

Perseverance, courage, kindness, faith, hope and optimism are expressions of spirituality and are essential to cope (Cabaço et al., 2018), resist, and help people re-evaluate the meaning of their life (Borges Charepe, Henriqueta De Jesús, \& Figueiredo 2010). According to Sessanna, Finnell, and Jezewski (2007), spirituality is a complex and abstract concept. Weathers, Mccarthy, and Coffey (2016, p.93) identified three attributes of spirituality in literature reviewed (from 1972 to 2005): "connectedness", "transcendence", and "meaning in life". They found in their research commonalities among all spiritual concepts such as "multidimensionality of spirituality"; "uniqueness of spirituality to each person"; "understanding that spirituality is broader than religious beliefs or affiliation". Spirituality is an important dimension for believers or nonbelievers (Cabaço et al. 2018; Puchalski 2001). According to Weathers, Mccarthy, and Coffey (2016):

Spirituality is a way of being in the world in which a person feels a sense of connectedness to self, others, and/or a higher power or nature; a sense of meaning in life; and transcendence beyond self, everyday living, and suffering (p. 93).

When people experience suffering, where fear and anguish are present, they often feel the need to follow a path of spiritual awakening. Students consumed by anxiety, frustration and fear have little scope to cultivate a spiritual path when they are under the sway of endless distorted thoughts being repeated over and over in their minds. When students believe in themselves, they tend to focus on the positive aspects of their lives. With the proper help (of a teacher), support and resources students encounter solutions to overcome adversities, generating a sense of empowerment and control in their own lives. "Spirituality means knowing that their lives have significance in a context beyond an everyday existence at the level of biological needs that lead to selfishness and aggression" (Spencer, n.d.). Spirituality involves exploring universal themes such as wisdom, love, compassion, courage, hope, altruism, truth, life after death, among others. The concept of spirituality can be considered as a key element in the search for the meaning of life and it is a crucial coping strategy at times of crisis and suffering (Caldeira et al., 2016). Finding spiritual paths helps students to rediscover new meanings in their lives.

Due to the mandatory confinement, any face-to-face strategies to facilitate group cohesion and solidarity were compromised. All group members, teacher and respective students, were involved in the process of recreating positive emotions, made possible through a digital tool - Blog. A Blog (shortened version of "weblog") is an online journal or informational website displaying information in reverse chronological order, with the latest posts appearing first, at the top. It is a platform where a writer or a group of writers share their views on an individual subject. This study aims to portray the experiences of five students and their respective teacher by recreating positive emotions (e.g. optimism, hope, courage, ...) through a digital tool (a Blog) during the mandatory quarantine. After self-deliberation, each of the participants will recount the challenges encountered. 


\section{Methodology}

A descriptive study, experience report type was conducted (Köche, 2011; Lüdke \& Andre, 2013; Soares et al., 2018). This study intends to recount the experiences lived by the authors during the established quarantine due to the coronavirus outbreak, between March and May of 2020. The teacher proposed to a group of five graduating nursing students to start a Blog, as a tool of spiritual practice (spiritual practices play an important role in coping mechanisms, in that they appear to be the first line of defence against distress and pain), where they would all share information about the virus and all its surrounded themes. This idea was established, since, during weekly online teaching sessions all the elements of the group discussed, for 15 minutes, about how they feel and how they cope with this new reality. How they reprogram their own minds to softening their suffering, anger and frustration by integrating positive feelings and emotions, through the Blog. This Blog would also provide support, since it would help the students to maintain a positive state of mind, thus improving their mental health during stressful times. All five students embraced this idea that was immediately taken into action.

The Blog was called "self-care in times of crisis" and it included a variety of digital material, varying from photos, videos, music, messages, comments, between others. There was a pre-established condition by the teacher that required that all posts shared in the Blog would generate positive emotions. At the end of this experience, the teacher requested all students to recount their experience and portray which emotions where generated. Suggestions were also incentivised. Group narratives were used in a modified Nominal Group Technique (NGT) process to generate and classify ideas that were analysed by content analysis (Pokorny, 1988; Yin, 2015). This process provides all members with an equal opportunity to participate and for their input to be considered. The NGT has been described as a 'useful consensus methodology' (Potter et al. 2004, p.126). In the first phase, the Crawford Slip Method (Crawford \& Demidovich, 1983) was used as a basis for initiating discussion related to the question and for the generation of ideas. This brainstorming technique used the digital platform of the university as a method of generating and organising data. Interaction between group members was discouraged during the idea-generating phase but encouraged in the second phase. Members were asked one question during the first phase: "Looking at your posts in the Blog, how many spiritual meanings do you find?" Responses were collected by the teacher. In the second phase, responses were discussed by group members and then sorted into general categories (Köche, 2011; Lüdke \& Andre, 2013; Soares et al., 2018; Yin, 2015). Finally, the group members prioritised these categories. The modified NGT was helpful in generating a list of spiritual meanings. Three categories emerged: compassion and kindness; self-awareness, and courage, that the group called "spiritual paths". Symbolic interactionism was used as a philosophical base that guided data collection and analysis (Blumer 1969; Burnier 2014; Monareng 2013). Symbolic interactionism is a sociological approach that explains people's interpretations of symbols and letters depending on their lived experiences.

\section{Ethical Aspects}

Having in consideration the importance of data privacy, the code "Blogger" was defined, and a number was added for each of the participants (e.g. Blogger\#1; Blogger\#2...Blogger\#6). All participants granted their informed consent for data publication.

\section{Results and Discussion}

The Blog was coordinated and assembled by all group elements. The main challenge encountered was finding attractive and innovative information that would generate positive emotions and keep the Blog active. Just like in online teaching, the didactic conception of material is fundamental (Rurato, and Gouveia 2004), it also depends on the level of guidance, the way it is organized, and the extent of communication used. In the Blog, the student is not just a receiver of 
information. Communication is multidirectional and it is possible to establish creative and open dialogue between all participants.

This experience allowed students and teacher to experience different realities. The role of apprentice, as an opportunity to learn how to generate positive emotions. The role of Blog promoters and supporters provided knowledge in order to guide and advise each other.

\section{Promoting spiritual paths}

Symbolic interactionism was used as a philosophical base that guided data collection and analysis (Blumer 1969; Burnier 2014; Monareng 2013). Central to symbolic interactionist thought is the idea that individuals use language and significant symbols in their communication with others. For symbolic interactionists, 'meaning' is one of the major elements in understanding human behavior, interactions and social processes.

The Blog accounted for 62 posts. About 36 were photos, which were divided into five distinguish themed groups: messages of compassion, love and kindness (17); messages of self-awareness/self-reflection (8); humor (5); general information (4) and daily life (2). The number of posted videos was 19, which were grouped into four different themes: music (8); gratitude messages (6); general information (4); humorous Giff (1). All the other posts were comments written by the Bloggers (8). These included encouraging words of strength and sharing daily positive experiences, as simple as a recipe for a carrot cake and a caramel pudding, which, according to Blogger\#3 "would taste amazing to lift up moral during the quarantine".

A numerous of posts were based in photos and videos, Luo and Kalman (2018), verify that the availability of videos summarizing contents are helpful and facilitate the learning experience during online teaching. Besides reinforcing knowledge, these videos increase motivation and enhance a greater involvement in a cognitive, emotional and social level (Mendes \& Encarnação, 2019). From the participants' recount of experiences, three major spiritual paths emerged: compassion and kindness related with posts of compassion, love and kindness (17); self-awareness related with posts of selfawareness/self-reflection (8) and courage related with posts of humor (5); general information (4) and daily life (2).

\section{First spiritual path: compassion and kindness}

"The world breaks everyone afterward many are strong at the broken places"

-Ernest Hemingway, a Farewell to Arms

Compassion and kindness are fundamental ways of behaving towards another human being, in particular when dealing with another person's suffering (Gottlieb 2013; Vieira 2017). Compassion and kindness are based on the belief that others, when in need of care and comfort, need to be treated gently. Compassion also enables the person to experience her own situation in a different light. Compassion can guide us to acts of kindness (Gottlieb 2013; Rowland \& Curry 2019). Kindness is an interpersonal skill. Compassion and acts of kindness are integrally tied to empathy and the will to help. Empathy is an essential element of compassion, caring, and respect. Empathy is relational, it requires the 'as if' quality, which means getting to know and understand another person - their thoughts and feelings.

In order to help nursing students to develop a sense of compassion for another person, it is important that they grow compassion for themselves first (self-compassion). This strategy is commonly used and three basic components of it were flourished through the Blog. Self-kindness, by extending kindness to oneself in the same way you would show kindness to someone else in need. Common humanity, by recognizing that what you are experiencing has been experienced by most people 
at one point in their lives. Mindfulness, the last component, by balancing one's pain with all the other current events on going in a person's live (Brown \& Ryan 2003; Gottlieb 2013).

Blogger\#1 states that this experience made her think about how other people were feeling. She constantly questioned herself "Are they as scared as I am? It was particularly challenging to post positive and hopeful messages at a time when I was feeling anxious and afraid. As a student, people have constantly told me that I could only give others what I own. So, at this time, how could I convey a sense of serenity on my posts if my world was falling apart? This anguish made me think and work daily, in order to find inner peace so that I could be there for my colleagues, as they were for me".

Bloguer\#2 states that "being a graduating nursing student in the time of COVID-19 encouraged us to think for ourselves, to always look for more information, thus improving our critical thinking and making us rethink our role as nurses in a society overwhelmed by a pandemic. With this new daily purpose of composing a Blog we were able to attribute a new meaning to our days, since we were helping others and ourselves at the same time thus building a new sense of solidarity".

Blogger\#3 mentions that "experiencing an unprecedented pandemic and consequently a mandatory quarantine, paused our lives in such a way that our thoughts about the future were inevitably negative and discouraging. A feeling of sadness and repulse arose from the unpredictability of the future, and from not knowing if we would be able to graduate. The social distancing with friends and family, during this period hindered our capability to overcome difficulties, since we felt a lack of support. We felt the need to develop different strategies in order to cope with our daily struggles. Some of these strategies included self-motivation and feeling management. The Blog was also helpful and composed one of the used strategies".

Blogger $\# 4$ refers that one of the shared videos "awoke a sense of self-care and reminded me the importance of body, mind and spirit cleansing, particularly during this social confinement. I dedicated time to work on myself and learned how to embrace my feelings and emotions, and respectively share them with others. This disputed various feelings, making me feel like I belonged to something bigger, showing me the importance of social solidarity. I took leverage of this situation and practiced Yoga and Meditation daily which deepened my knowledge and promoted my wellbeing".

Blogger\#5 describes that "social distancing limited our support systems. We could no longer count on our friends or family to help us overcome adversities. The Blog gave us the motivation to increase our knowledge, emotional intelligence and to embrace or feelings by learning how to manage them. All the positive quotes shared in the Blog lightened up our daily lives".

Blogger\#6 verified that "the chaos around the world and all the horrifying deaths due to COVID-19 were brought to us by the media. It felt like It was coming towards us and forced us to pause our lives. The Blog allowed us to think about our weaknesses and vulnerabilities and turn them into strengths. Uncovering and discovering strengths is a part of a larger process. The process of getting to know people. To learn their current situation, including their story, the important things in their lives, their values, what they have been through, the challenges they have faced and are currently facing, and the things they would like to achieve in a near future".

\section{Second spiritual path: self-awareness}

"Be strong now, because things will get better.

It might be stormy now, but it can't rain forever “.

-Author Unknown

Self-awareness is the ability to see yourself clearly and objectively through reflection and introspection (Blakemore \& Frith 2003; Young 2014; Sutton 2016). People create meaning through complex processes that involve understanding and interpreting present events in light of past experiences and previously acquired knowledge (Gottlieb 2013; Narayanasamy et 
al. 2004). One way of creating meaning is by interpreting the unfamiliar and relating it to something that is familiar or already known (Chavoix \& Insausti, 2017).

Self-awareness implies several areas likely organized in specific networks. The medial prefrontal cortex is the region that most constantly identifies with this network (Chavoix \& Insausti, 2017). There have been implicated other cortical and subcortical areas. However, their role in self-awareness remains obscure (Chavoix \& Insausti, 2017). Another approach, in order to understand an experience is dwelling on it and reliving the story. Each time she retells her story, she may come up with a new interpretation to explain the events and how they happened (Gottlieb, 2013). Discovering the mean of something refers to the ways in which people utilise their spiritual beliefs to try to make sense out of the experiences they lived. Prayer can reinforce those spiritual beliefs and promote hope by providing a connection with a sacred and self-transcending dimension (Simão et al., 2016).

Blogger\#1 mentions, "I looked in the mirror and did not recognize myself. I had huge dark circles under my eyes from being sleep deprived. The daily conversation topics were always the same (COVID-19 .. COVID-19 ... COVID-19). I was constantly watching the news and found myself in a dark place, filled with negative emotions. I decided to create a daily routine in order to think positive, by taking control of my actions, behaviours and thoughts. This whole process was a learning experience, I am grateful for the Blog!".

Bloguer \#2 declares that "The Blog provided us a daily dose of positive thoughts during these dark times, through the shared videos, photos and links to all kinds of documents and articles. We were able to share the most varied information, ranging from inspirational daily quotes to COVID-19 number reports and several videos from the most acclaimed and distinguished nurse theorists, like Jean Watson. This brilliant idea affected in a positive way our daily life as well as our respective family members, since we were able to lift up everyone's mood and convey a sense of serenity in the middle of chaos".

Blogger\#3 expresses how "the daily viewing of motivational posts in the Blog, allowed me to build up a positive state of mind in order to cope with this pandemic. There is no doubt that these posts got me through the day with a newer, fresher and more positive pair of eyes. Due to the uncertainty of the future, I would feel stressed and anguished on a daily basis. The positive and motivational posts allowed me to become calmer and more positive".

Blogger\#4 states that "When first approached with the idea of creating a Blog, in order to find the meaning of this new reality that we are currently living, I was sceptical. After all, how would a Blog help us deal with our feelings, emotions, the current lack of freedom and social distancing? This initiative surprised me in a positive way since we all grew closer. The posts were able to lift-up my moral and make me a more positive person. These two qualities are the ones that can best describe our teacher and I feel safe to say that she was able to pass that on".

Blogger\#5 acknowledges that "my favourite post was shared by the teacher. It was a controversial video that had a different perspective (positive one) on the COVID-19 pandemic. Even though, not everyone agreed, it represented well the meaning of our Blog, which was to show the world from a different point of view. This encouraged us to think outside of the box and put ourselves in other people's shoes".

Blogger\#6 revealed that "the process of assimilating the struggles and uniqueness of the current events revealed to be longer and more exhausting than ever before. It felt like we were living a biblical passage where they describe the Egyptian pest. Being responsible for other people's training implies a need of self-awareness and self-reflection. It is important to acknowledge our values and be open to all kinds of spiritual development (e.g. meditation, daily prayer), besides acquiring maturity, it allows you to find your core and restart the day in a more positive way. Restart building new meaningful connections and emotions. Develop new perspectives on live and fill it with optimism and joy. I had never posted on a Blog before and found it an enormous learning experience". 


\section{Third spiritual path: courage}

"Hope is wishing something would happen;

Faith is believing something will happen;

Courage is making something happen."

\section{-Author Unknown}

Courage is an emotion that generates inner strength in humans (Koerner 2014; Putman 2001). We can consider someone to be courageous when they fight their immediate fears to face a new situation, meaning that they go beyond their known domain. This involves taking risks. Doing the right thing often takes courage because it often entails doing something that is not easy (Gottlieb, 2013). Courage is a strength that is made up of several other character traits, including bravery, persistence, integrity, and vitality (Peterson \& Seligman 2004; Pury \& Kowalski 2007).

The lack of courage to act, is often rooted in fear. One technique used to contain or overcome fear is for the nursing student to ask herself or think of a situation or an event in which she overcame a fear. In the Blog the nursing student can describe the event leading up to the incident, its context, her thoughts and feelings at the time, how she reacted, and her subsequent feelings and reactions after she took action. She can ask herself "What was the thing I feared most? How did I feel? Did I feel that I did the right thing?“" (Gottlieb 2013, p. 157). Answering these questions will determine the link between showing courage and feeling good about themselves. Courage grows out of voicing one's opinion, being heard and taking responsibility for one's actions.

Blogger\#1 mentions "how writing in a Blog helped me feel heard when exposing my feelings. It improved my selfconfidence. I was definitely gaining courage. It helped me understand that I was not alone, my colleagues and the entire world were in the same situation. The Blog provided me with a sense of serenity, which consequently helped my whole family feel calmer and more positive".

Bloguer\#2 states "I am honoured to say that I was able to participate in such an experience and I am fully assured that this idea should be implemented during all the internships completed by students. This would be a new way to support each other and to guaranty the effectiveness of group work which is one of the major foundations of nurse work and a necessary requirement in order to be a good nurse".

Blogger\#3 points out that "This initiative influenced both, her personal and academic life, since it generated a proximity between the workgroup. The Blog was advantageous to our learning process since it motivated and encourage us to be more successful at an academic level. We were able to be more interactive in our weekly counselling online meetings and perform better in written reports".

Blogger\#4 considers that "the numerous advantages of the Blog created an effect on a personal and social level. By sharing our posts with our families, we improved each other's days. Our group dynamic improved, which consequently generated better meetings and enhanced our academic work. Professionally, it helped me acquire the necessary tools and courage to provide adequate and quality care, in a domestic context to an elderly person with COVID-19, as an informal caregiver".

Blogger\#5 declares that "the advantages of the Blog were reflected in our academic results. Motivation and positive feelings, on a daily basis, empowered us to do better at an academic level. Besides that, it enhanced our groupwork and the relationship between teacher-student and student-teacher, which generated better online meetings".

Blogger\#6 thinks that "Listing to each other's voices and taking into consideration their needs gave me the will and courage to keep an active voice in the Blog. It helped me focus on the things that truly generate happiness and made me realize that humour can promote sensations, such as wellbeing, stress reduce, inspiration, motivation, hope and courage." 


\section{Final Considerations}

The COVID-19 pandemic altered live as we know it. It modified our work environments, our relationships and it caused social distancing. Our ways of teaching were also affected forcing us to switch from the traditional way of teaching to online lessons. The nursing students, that were currently doing their clinical rotations in a hospital context, saw their lives disrupted when forced to interrupt due to a mandatory quarantine.

Online teaching provided a more self-conscious and autonomous learning experience for the students, allowing for a greater geographical flexibility, reducing economic and cultural disparities, and producing a fairer system overall. For all its benefits, it was not enough. We witnessed inspiring and unique moments, showing the ability for the human race to quickly adapt and grow in adverse scenarios. Moments where fear and uncertainty revealed to be stronger than ever and top of mind in the population. We were able to manage oneself and this evermore VUCA (Volatility, Uncertainty, Complexity and Ambiguity) environment that was caused by dealing with a mandatory quarantine and an unsettling feeling that time had come to a halt, (freezing personal goals and ambitions such as being a nurse) by pushing ourselves further than ever, and despite of social distancing feel more close than ever. Changing to a more positive perspective in the midst of this chaos was ultimately the trigger for the Blog, allowing its participants to overcome the anxiety, the sadness, reducing stress and fears, all through neuro-linguistic programming and acquired coping skills to manage these feelings. The uprising and settling of a new normal generated a new sense of commitment and consequently new opportunities. Thoughts were organized, and the learning experience was continuous. Everyone had a chance to tell their stories and to test and analyse their knowledge. This allowed fears to be transformed in courage and helped establishing bonds. It is fundamental to help these graduating nursing students to maintain their mental health. It is indispensable for them to have the necessary coping skills to deal with negative emotions. This will generate the strength needed to properly nurse a patient and allow the patients themselves to uncover their strengths and feel hopeful again. Working with strengths is simply an extension of the natural way humans deal with threats. By identifying, mobilizing, and capitalizing on existing strengths they cope more effectively with the faced challenges.

After the deliberation and elaboration of the present manuscript, it is comprehensive that the Blog empowered both teacher and their respective students to achieve their own goals and find new meanings in their lives, through the three spiritual paths: compassion and kindness; self-awareness and courage. It is suggested in future research that practice in writing and organization of thoughts through a Blog might improve student confidence and provide more humanized learning in school and improving nursing practices in the real world. All participants agreed that this kind of digital tools should be used throughout the bachelor's in nursing which generates a more humanized way of teaching, allowing students to see beyond University walls.

\section{References}

Blakemore, S. J., \& Frith, C. (2003). Self-awareness and action. In Current Opinion in Neurobiology. https://doi.org/10.1016/S0959-4388(03)00043-6

Blumer, H. (1969). Symbolic Interactionism: Perspective and Method. University of California Press. https://books.google.pt/books?id=HVuognZFofoC\&p rintsec $=$ frontcover $\& \mathrm{hl}=\mathrm{pt}-\mathrm{PT} \# \mathrm{v}=$ onepage $\& \mathrm{q} \& \mathrm{f}=$ false

Bowen, H. J., Kark, S. M., \& Kensinger, E. A. (2018). NEVER forget: negative emotional valence enhances recapitulation. Psychonomic Bulletin \& Review, 25(3), 870-891. https://doi.org/10.3758/s13423-017-1313-9

Brown, K. W., \& Ryan, R. M. (2003). The Benefits of Being Present: Mindfulness and Its Role in Psychological Well-Being. In Journal of Personality and Social Psychology. https://doi.org/10.1037/0022-3514.84.4.822

Burnier, D. (2014). Administrative Theory \& Praxis Making It Meaning Full: Postmodern Public Administration and Symbolic Interactionism. Taylor \& Francis, 27(3), 498-516. https://doi.org/10.1080/10841806.2005.11029503

Cabaço, S. R., Caldeira, S., Vieira, M., \& Rodgers, B. (2018). Spiritual Coping: A Focus of New Nursing Diagnoses. International Journal of Nursing Knowledge, 29(3), 156-164. https://doi.org/10.1111/2047-3095.12171 
Caldeira, S., Simões Figueiredo, A., da Conceição, A., Ermel, C., Mendes, J., Chaves, E., Campos de Carvalho, E., \& Vieira, M. (2016). Spirituality in the Undergraduate Curricula of Nursing Schools in Portugal and São Paulo-Brazil. Religions, 7(11), 134. https://doi.org/10.3390/rel7110134

Cassell, E. J. (2004). The Nature of Suffering and the Goals of Medicine. Oxford University Press Inc.

Chavoix, C., \& Insausti, R. (2017). Self-awareness and the medial temporal lobe in neurodegenerative diseases. In Neuroscience and Biobehavioral Reviews (Vol. 78, pp. 1-12). Elsevier Ltd. https://doi.org/10.1016/j.neubiorev.2017.04.015

Crawford, C., \& Demidovich, J. (1983). Crawford slip method. how to mobilize brainpower by think tank technology. https://apps.dtic.mil/sti/citations/ADA162558

Encarnação, P., Oliveira, C. C., \& Martins, T. (2018). Psychometric properties of the suffering assessment questionnaire in adults with chronic diseases or lifethreatening illness. Scandinavian Journal of Caring Sciences, 32(4), 1279-1287. https://doi.org/10.1111/scs.12569

Gottlieb, L. (2013). Strengths-Based Nursing Care: Health And Healing For Person And Family. Springer Publishing Company.

Köche, J. C. (2011). Fundamentossde Metodologia Científica - Teoria da Ciência e iniciação à pesquisa (1ª, Vol. 1). Petrópolis, RJ: Vozes Ltda. http://www.vozes.com.br

Koerner, M. M. (2014). Courage as identity work: Accounts of workplace courage. Academy of Management Journal. https://doi.org/10.5465/amj.2010.0641

Lüdke, M., \& Andre, M. E. D. A. (2013). Pesquisa em Educação: abordagens qualitativas (2a). E.P.U. https://www.ufrgs.br/bibedu/pesquisa-em-educacao-ia/

Luo, S., \& Kalman, M. (2018). Using summary videos in online classes for nursing students: A mixed methods study. Nurse Education Today, 71, 211-219. https://doi.org/10.1016/j.nedt.2018.09.032

Mendes, G., \& Encarnação, P. (2019). Online distance higher education: possibilities and challenges for faculty. Congreso Universitario Internacional Sobre La Comunicación En La Profesión y En La Universidad de Hoy: Contenidos, Investigación, Innovación y Docencia (CUICIID), $711-713$.

Monareng, L. V. (2013). An exploration of how spiritual nursing care is applied in clinical nursing practice. Health SA Gesondheid, 18(1). https://doi.org/10.4102/hsag.v18i1.635

Narayanasamy, A., Clissett, P., Parumal, L., Thompson, D., Annasamy, S., \& Edge, R. (2004). Responses to the spiritual needs of older people. Journal of Advanced Nursing, 48(1), 6-16. https://doi.org/10.1111/j.1365-2648.2004.03163.x

Ornell, F., Schuch, J. B., Sordi, A. O., \& Kessler, F. H. P. (2020). “"Pandemic fear”” and COVID-19: Mental health burden and strategies. In Brazilian Journal of Psychiatry (Vol. 42, Issue 3, pp. 232-235). Associacao Brasileira de Psiquiatria. https://doi.org/10.1590/1516-4446-2020-0008

Peterson, C., \& Seligman, M. (2004). Introduction: Strenghts of courage. In C. Peterson \& M. Seligman (Eds.), Character Strengths and Virtues: A Handbook and Classification (pp. 199-212). Oxford University Press Inc.

Pokorny, L. J. |An. O. (1988). Introducing a Modified Nominal Group Technique for Issue Identification. Evaluation Practice, 9(2), 40-44.

Potter, M., Hamer, P. W., Gordon, S., \& Hamer, P. (2004). The Nominal Group Technique: A useful consensus methodology in physiotherapy research. In NZ Journal of Physiotherapy (Vol. 32). https://www.researchgate.net/publication/254724490

Puchalski, C. (2001). Spirituality and health: the art of compassionate medicine. Hospital Physician, 37(3), 30-36.

Pury, C. L. S., \& Kowalski, R. M. (2007). Human strengths, courageous actions, and general and personal courage. The Journal of Positive Psychology, 2(2), 120-128. https://doi.org/10.1080/17439760701228813

Putman, D. (2001). The emotions of courage. Journal of Social Philosophy. https://doi.org/10.1111/0047-2786.00107

Rowland, L., \& Curry, O. S. (2019). A range of kindness activities boost happiness. In Journal of Social Psychology. 159(3), 340-343). Routledge. https://doi.org/10.1080/00224545.2018.1469461

Sessanna, L., Finnell, D., \& Jezewski, M. A. (2007). Spirituality in Nursing and Health-Related Literature: A Concept Analysis. Journal of Holistic Nursing, 25(4), 252-262. https://doi.org/10.1177/0898010107303890

Simão, T., Caldeira, S., \& de Carvalho, E. (2016). The Effect of Prayer on Patients' Health: Systematic Literature Review. Religions, 7(1), 11. https://doi.org/10.3390/rel7010011

Soares, A., Dorlivete, P., Shitsuka, M., Parreira, F. J., \& Shitsuka, R. (2018). Metodologia da pesquisa científica (Núcleo de Tecnologia Educacional da Universidade Federal de Santa Maria. https://repositorio.ufsm.br/bitstream/handle/1/15824/Lic_Computacao_Metodologia-Pesquisa-

Cientifica.pdf?sequence $=1$

Spencer, M. (n.d.). What is spirituality? A personal exploration.

Sutton, A. (2016). Measuring the effects of self-awareness: Construction of the self-awareness outcomes questionnaire. Europe's Journal of Psychology. https://doi.org/10.5964/ejop.v12i4.1178

Vieira, M. (2017). Ser enfermeiro: da compaixão à proficiência (3rd ed.). Universidade Católica Portuguesa.

Weathers, E., Mccarthy, G., \& Coffey, A. (2016). Concept Analysis of Spirituality: An Evolutionary Approach. Nursing Forum, 51(2), 79-96. https://doi.org/10.1111/nuf.12128 
Research, Society and Development, v. 10, n. 5, e4510514710, 2021

(CC BY 4.0) | ISSN 2525-3409 | DOI: http://dx.doi.org/10.33448/rsd-v10i5.14710

Wright, L. M. (2020). Conquering Fear During Social-Distancing or Self-Quarantine: Even Fearing the Disappearance of Popcorn. Journal of Family Nursing, 26(3), 187-189. https://doi.org/10.1177/1074840720923421

Yin, R. K. (2015). Estudo de caso: planejamento e métodos. Bookman.

Young, G. B. (2014). Self-Awareness. In Encyclopedia of the Neurological Sciences. https://doi.org/10.1016/B978-0-12-385157-4.00340-7 